\title{
Microstructure and Morphology Control of Potassium Magnesium Titanates and Sodium Iron Titanates by Molten Salt Synthesis
}

\author{
Haoran Zhang ${ }^{\dagger}$, Mengshuo Li ${ }^{\dagger}$, Ze Zhou, Liming Shen * and Ningzhong Bao * \\ State Key Laboratory of Material-Oriented Chemical Engineering, College of Chemical Engineering, \\ Nanjing Tech University, Nanjing 210009, China; zhr111@njtech.edu.cn (H.Z.); lmshlove@njtech.edu.cn (M.L.); \\ 1461749960@njtech.edu.cn (Z.Z.) \\ * Correspondence: lshen@njtech.edu.cn (L.S.); nzhbao@njtech.edu.cn (N.B.); Tel.: +86-25-8317-2244 (N.B.); \\ Fax: +86-25-8317-2244 (N.B.) \\ + These authors contributed equally.
}

Received: 11 April 2019; Accepted: 9 May 2019; Published: 14 May 2019

\begin{abstract}
Titanates materials have attracted considerable interest due to their unusual functional and structural properties for many applications such as high-performance composites, devices, etc. Thus, the development of a large-scale synthesis method for preparing high-quality titanates at a low cost is desired. In this study, a series of quaternary titanates including $\mathrm{K}_{0.8} \mathrm{Mg}_{0.4} \mathrm{Ti}_{1.6} \mathrm{O}_{4}$, $\mathrm{Na}_{0.9} \mathrm{Mg}_{0.45} \mathrm{Ti}_{1.55} \mathrm{O}_{4}, \mathrm{Na}_{0.75} \mathrm{Fe}_{0.75} \mathrm{Ti}_{0.25} \mathrm{O}_{2}, \mathrm{NaFeTiO}_{4}$, and $\mathrm{K}_{2.3} \mathrm{Fe}_{2.3} \mathrm{Ti}_{5.7} \mathrm{O}_{16}$ are synthesized by a simple molten salt method using inexpensive salts of $\mathrm{KCl}$ and $\mathrm{NaCl}$. The starting materials, intermediate products, final products, and their transformations were studied by using TG-DSC, XRD, SEM, and EDS. The results show that the grain size, morphology, and chemical composition of the synthesized quaternary titanates can be controlled simply by varying the experimental conditions. The molar ratio of mixed molten salts is critical to the morphology of products. When $\mathrm{KCl}: \mathrm{NaCl}=3: 1$, the morphology of $\mathrm{K}_{0.8} \mathrm{Mg}_{0.4} \mathrm{Ti}_{1.6} \mathrm{O}_{4}$ changes from platelet to board and then bar-like by increasing the molar ratio of molten salt $(\mathrm{KCl}-\mathrm{NaCl})$ to raw materials from 0.7 to 2.5. $\mathrm{NaFeTiO}_{4}$ needles and $\mathrm{Na}_{0.75} \mathrm{Fe}_{0.75} \mathrm{Ti}_{0.25} \mathrm{O}_{2}$ platelets are obtained when the molar ratio of molten salt $(\mathrm{NaCl})$ to raw materials is 4. Pure phase of $\mathrm{Na}_{0.9} \mathrm{Mg}_{0.45} \mathrm{Ti}_{1.55} \mathrm{O}_{4}$ and $\mathrm{K}_{2.3} \mathrm{Fe}_{2.3} \mathrm{Ti}_{5.7} \mathrm{O}_{16}$ are also observed. The formation and growth mechanisms of both potassium magnesium titanates and sodium iron titanates are discussed based on the characterization results.
\end{abstract}

Keywords: titanates; morphology; molten salt; crystal growth; Formation

\section{Introduction}

The titanates is a group of inorganic compounds consisting of titanium, oxygen, and one or more other metallic elements. Dependent on the linkage method of the structure unit of $\mathrm{TiO}_{6}$ octahedra, titanates may exhibit cage, tunnel, and layered structures. The commonly employed titanates in industrial applications include $\mathrm{CaTiO}_{3}, \mathrm{BaTiO}_{3}, \mathrm{SrTiO}_{3}$, and $\mathrm{M}_{2} \mathrm{O} . \mathrm{nTiO}{ }_{2}(\mathrm{M}=\mathrm{K} / \mathrm{Na}, \mathrm{n}=1 \sim 8)$, covering a wide range from the medical to electrical and automotive industries. As opposed to the ternary titanates with well-investigated properties and developed applications, quaternary titanates are still in the exploring stage, partly due to the large range of compositions and the complex structural deviation. Among all quaternary titanates, $\mathrm{K}_{2} \mathrm{O}-\mathrm{MgO}-\mathrm{TiO}_{2}$ and $\mathrm{K}_{2} \mathrm{O} / \mathrm{Na}_{2} \mathrm{O}-\mathrm{Fe}_{2} \mathrm{O}_{3}-\mathrm{TiO}_{2}$ are the most studied systems to investigate the reaction boundary and crystallographic structure. In order to represent both the stoichiometric and nonstoichiometric compositions, two forms of formula, $\mathrm{A}_{x}\left(\mathrm{~B}_{x / 2}{ }^{\mathrm{II}} \mathrm{Ti}_{y-x / 2}\right) \mathrm{O}_{2 y}$ and $\mathrm{A}_{x}\left(\mathrm{~B}_{x}{ }^{\mathrm{III}} \mathrm{Ti}_{y-x}\right) \mathrm{O}_{2 y}(y=1,2,4,8)$ with $\mathrm{A}=$ alkali metal ions and $\mathrm{B}=$ divalent $\left(\mathrm{B}^{\mathrm{II}}\right)$ or trivalent $\left(\mathrm{B}^{\mathrm{III}}\right)$ ions, are generally used. 
The $\mathrm{A}_{x}\left(\mathrm{~B}_{x / 2}{ }^{\mathrm{II}} \mathrm{Ti}_{8-x / 2}\right) \mathrm{O}_{16}$ and $\mathrm{A}_{x}\left(\mathrm{~B}_{x}{ }^{\mathrm{III}} \mathrm{Ti}_{8-x}\right) \mathrm{O}_{16}$, with the $x$ value in the range of $1.5<x \leq 2.0$, have hollandite structure. Fujiki et al. [1] prepared hollandite $\mathrm{K}_{1.6} \mathrm{Mg}_{0.8} \mathrm{Ti}_{7.2} \mathrm{O}_{16}$ and $\mathrm{K}_{1.6} \mathrm{Al}_{1.6} \mathrm{Ti}_{6.4} \mathrm{O}_{16}$ crystals using the $\mathrm{K}_{2} \mathrm{MoO}_{4}-\mathrm{MoO}_{3}$ flux melting method. Endo et al. [2] obtained hollandite $\mathrm{K}_{1.6} \mathrm{Fe}_{1.6} \mathrm{Ti}_{6.4} \mathrm{O}_{16}$ in the shape of a needle and $\alpha$-phase $\mathrm{K}_{2.3} \mathrm{Fe}_{2.3} \mathrm{Ti}_{5.7} \mathrm{O}_{16}$ in the shape of platelet using a similar synthesis method and observed the ionic conductivity. Park et al. [3] generated a composite of short fibers of hollandite $\mathrm{K}_{2} \mathrm{MgTi}_{7} \mathrm{O}_{16}$ and glass with enhanced bending strength. Chen et al. [4] synthesized hollandite $\mathrm{K}_{1.54} \mathrm{Mg}_{0.77} \mathrm{Ti}_{7.33} \mathrm{O}_{16}$ whiskers with high near-infrared reflectivity. Akieh et al. [5] prepared $\mathrm{Na}_{2} \mathrm{Fe}_{2} \mathrm{Ti}_{6} \mathrm{O}_{16}$ by solid-state method and investigated the ion exchange properties by removing ionic. $\mathrm{Ni}$. Knyazev et al. [6] investigated the structure and thermal expansion of synthesized $\mathrm{K}_{2} \mathrm{Fe}_{2} \mathrm{Ti}_{6} \mathrm{O}_{16}$ with hollandite structure and $\mathrm{Na}_{2} \mathrm{Fe}_{2} \mathrm{Ti}_{6} \mathrm{O}_{16}$ with freudenbergite structure.

The research on $\mathrm{A}_{x}\left(\mathrm{~B}_{x / 2}{ }^{\mathrm{II}} \mathrm{Ti}_{4-x / 2}\right) \mathrm{O}_{8}$ and $\mathrm{A}_{x}\left(\mathrm{~B}_{x}{ }^{\mathrm{III}} \mathrm{Ti}_{4-x}\right) \mathrm{O}_{8}$ is relatively rare. Hou et al. [7] reported on the solid-state reaction synthesis of sodium titanate bronze-type $\mathrm{NaFeTi}_{3} \mathrm{O}_{8}$ as an anode material for sodium-ion batteries exhibiting a discharge capacity of $170.7 \mathrm{~mA} \cdot \mathrm{h} \cdot \mathrm{g}^{-1}$ at a current density of $20 \mathrm{~mA} \cdot \mathrm{g}^{-1}$. $\mathrm{NaFeTiO}_{4}$ and $\mathrm{K}_{0.8} \mathrm{Mg}_{0.4} \mathrm{Ti}_{1.6} \mathrm{O}_{4}$ are the two representative compounds for $\mathrm{A}_{x}\left(\mathrm{~B}_{x / 2}{ }^{\mathrm{II}} \mathrm{Ti}_{2-x / 2}\right) \mathrm{O}_{4}$ and $\mathrm{A}_{x}\left(\mathrm{~B}_{x}{ }^{\mathrm{III}} \mathrm{Ti}_{2-x}\right) \mathrm{O}_{4}$, respectively. $\mathrm{NaFeTiO}_{4}$ is a calcium-ferrite type octatitanate. Archaimbault et al. [8] found that $\mathrm{Na}_{0.875} \mathrm{Fe}_{0.875} \mathrm{Ti}_{1.125} \mathrm{O}_{4}$ is a unique composition. Sodium titanate bronze-type $\mathrm{NaFeTi}_{3} \mathrm{O}_{8}$ $(x<0.875)$ and calcium-ferrite type $\mathrm{NaFeTiO}_{4}(x>0.875)$ were found on each side of the composition $x=0.875$. Mumme et al. [9] prepared $\mathrm{Na}_{x} \mathrm{Fe}_{x} \mathrm{Ti}_{2-x} \mathrm{O}_{4}$ with a small structural variation within the range of $0.75<x<0.9$. Kuhn et al. [10] conducted sodium extraction on $\mathrm{Na}_{0.875} \mathrm{Fe}_{0.875} \mathrm{Ti}_{1.125} \mathrm{O}_{4}$ and studied the conductivity. $\mathrm{K}_{0.8} \mathrm{Mg}_{0.4} \mathrm{Ti}_{1.6} \mathrm{O}_{4}$ has lepidocrocite-like structure and is used to produce friction materials. Tan et al. [11] synthesized $\mathrm{K}_{0.8} \mathrm{Mg}_{0.4} \mathrm{Ti}_{1.6} \mathrm{O}_{4}$ platy powders by a flux method to remove copper ions from water pollutants through ion-exchange adsorption. Liu et al. [12] prepared $\mathrm{K}_{0.8} \mathrm{Mg}_{0.4} \mathrm{Ti}_{1.6} \mathrm{O}_{4}$ platelets and porous ceramics to remove $\mathrm{Ni}$ ions from wastewater.

Both $\mathrm{A}_{x}\left(\mathrm{~B}_{x / 2}{ }^{\mathrm{II}} \mathrm{Ti}_{1-x / 2}\right) \mathrm{O}_{2}$ and $\mathrm{A}_{x}\left(\mathrm{~B}_{x}{ }^{\mathrm{III}} \mathrm{Ti}_{1-x}\right) \mathrm{O}_{2}$ have attracted increased interest due to the potential application of layered $\alpha-\mathrm{NaFeO}_{2}$ structure for Na-ion cathode materials. Li et al. [13] prepared $\mathrm{Na}_{1-x} \mathrm{Fe}_{1-x} \mathrm{Ti}_{x} \mathrm{O}_{2}(0 \leq x \leq 0.28)$ with $\alpha-\mathrm{NaFeO}_{2}$ structure and $\mathrm{K}_{1-x} \mathrm{Fe}_{1-x} \mathrm{Ti}_{x} \mathrm{O}_{2}(0 \leq x<0.20)$ with $\beta$-cristobalite structure. Fujishiro et al. [14] synthesized $\mathrm{Na}_{0.4} \mathrm{M}_{0.2} \mathrm{Ti}_{0.8} \mathrm{O}_{2}(\mathrm{M}=\mathrm{Co}, \mathrm{Ni}$, and $\mathrm{Fe})$ with $\alpha-\mathrm{NaFeO}_{2}$ structure and measured their thermoelectric properties. Thorne et al. [15] studied the structural stabilization of iron containing cathode materials by substituting some iron in $\alpha-\mathrm{NaFeO}_{2}$ with titanium to produce $\mathrm{Na}_{x} \mathrm{Fe}_{x} \mathrm{Ti}_{1-x} \mathrm{O}_{2}(0.75 \leq x \leq 1.0)$.

The studies above mainly focus on the investigation of compositional and structural variations and the potential applications on specific compositions. Various compositions have been made by different kinds of synthesis methods, such as high-temperature calcination, molten salt synthesis, kneading-drying-calcination (KDC), etc. [1-15]. The subject of this study is to achieve a stable production of high-quality quaternary octatitanates with controllable morphology and narrow size distribution for potential applications in inorganic fiber-reinforced composites and sodium ion batteries. The molten salt method and low-cost raw materials have thus been exclusively used for future scalable industry production. Through the adjustment of the content $(\alpha)$ of molten salt in raw materials, the ratio $(\beta)$ of $\mathrm{KCl}$ in $\mathrm{KCl}-\mathrm{NaCl}$ molten salt, and the reaction temperature and time, we obtained pure phase of lepidocrocite-like $\mathrm{K}_{0.8} \mathrm{Mg}_{0.4} \mathrm{Ti}_{1.6} \mathrm{O}_{4}$ and $\mathrm{Na}_{0.9} \mathrm{Mg}_{0.45} \mathrm{Ti}_{1.55} \mathrm{O}_{4}$, calcium-ferrite type $\mathrm{NaFeTiO}_{4}$, $\mathrm{Na}_{0.75} \mathrm{Fe}_{0.75} \mathrm{Ti}_{0.25} \mathrm{O}_{2}$ with layered $\alpha-\mathrm{NaFeO}_{2}$ structure, and $\alpha$-phase $\mathrm{K}_{2.3} \mathrm{Fe}_{2.3} \mathrm{Ti}_{5.7} \mathrm{O}_{16}$. Three KMTO products, namely $\mathrm{K}_{0.8} \mathrm{Mg}_{0.8} \mathrm{Ti}_{1.6} \mathrm{O}_{4}$ platelets, $\mathrm{K}_{0.8} \mathrm{Mg}_{0.8} \mathrm{Ti}_{1.6} \mathrm{O}_{4}$ boards, and $\mathrm{K}_{0.8} \mathrm{Mg}_{0.8} \mathrm{Ti}_{1.6} \mathrm{O}_{4}$ bars, are obtained at three sets of optimum conditions $\left(\alpha=0.7,1.5\right.$, and $\left.2.5 ; \beta=0.75 ; \mathrm{T}=1050{ }^{\circ} \mathrm{C} ; \mathrm{t}=4 \mathrm{~h}\right)$. Two NFTO products, namely $\mathrm{NaFeTiO}_{4}$ needles and $\mathrm{Na}_{0.75} \mathrm{Fe}_{0.75} \mathrm{Ti}_{0.25} \mathrm{O}_{2}$ platelets, are obtained when $\mathrm{T}=900$ and $1000^{\circ} \mathrm{C} ; \alpha=4 ; \beta=0$; and $\mathrm{t}=4$. The products and their intermediate products are characterized by scanning electron microscopy, $\mathrm{X}$-ray diffraction, and thermogravimetric analysis for a better understanding of their formation and growth processes. The current synthesis procedure can be scaled for controllable production of these types of titanates. 


\section{Materials and Methods}

\subsection{Reagents and Materials}

Titanium dioxide $\left(\mathrm{TiO}_{2}\right)$, iron oxide $\left(\mathrm{Fe}_{2} \mathrm{O}_{3}\right)$, and magnesium carbonate basic pentahydrate $\left(4 \mathrm{MgCO}_{3} \cdot \mathrm{Mg}(\mathrm{OH})_{2} \cdot 5 \mathrm{H}_{2} \mathrm{O}\right)$ were purchased from Sinopharm Chemical Reagent Co., Ltd. (Shanghai, China). Potassium carbonate $\left(\mathrm{K}_{2} \mathrm{CO}_{3}\right)$, sodium carbonate $\left(\mathrm{Na}_{2} \mathrm{CO}_{3}\right)$, sodium chloride $(\mathrm{NaCl})$, and potassium chloride $(\mathrm{KCl})$ were purchased from Shanghai Lingfeng Chemical Reagent Co., Ltd., China. Ilmenite $\left(\mathrm{FeTiO}_{3}\right)$ was purchased from Jiangsu Taibai Group Co., Ltd. (Zhenjiang, China). The alumina crucibles $(50 \mathrm{~mL})$ used for calcination were purchased from Nanjing Wanqing Chemical Glass Instrument Co., Ltd. (Nanjing, China).

\subsection{Adjustment of Molten Salt Content}

The molten salt content $\alpha$ is defined as the molar ratio of molten salt to raw materials, namely

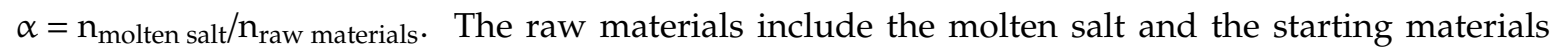
(see 2.3 and 2.4). The molten salt ratio $\beta$ is defined as the molar ratio of $\mathrm{KCl}$ to $\mathrm{KCl}-\mathrm{NaCl}$, namely $\beta=\mathrm{n}_{\mathrm{KCl}} / \mathrm{n}_{\text {mixture of } \mathrm{NaCl}-\mathrm{KCl}}$.

\subsection{Preparation of Potassium Magnesium Titanates (KMTO)}

Potassium magnesium titanates were produced by the molten salt synthesis method. The starting materials of $\mathrm{TiO}_{2}, \mathrm{~K}_{2} \mathrm{CO}_{3}$, and $4 \mathrm{MgCO}_{3} \cdot \mathrm{Mg}(\mathrm{OH})_{2} \cdot 5 \mathrm{H}_{2} \mathrm{O}$ (Ti: $\left.\mathrm{K}: \mathrm{Mg}=4: 2: 1\right)$ were mixed with $\mathrm{KCl}-\mathrm{NaCl}$ molten salt $(\beta=0,0.3,0.45,0.75,0.85$, and 1$)$ at a certain molar ratio $(\alpha=0,0.5,0.7,1.5,2.0,2.5$, and 6.0$)$. The mixture was calcined at $750,850,950$, and $1050^{\circ} \mathrm{C}$ for 2,4 , or $6 \mathrm{~h}$ for the procedure optimization. After cooling to room temperature, the product was washed with distilled water to remove salt residue and was then dried at $100{ }^{\circ} \mathrm{C}$ for $10 \mathrm{~h}$. Three kinds of $\mathrm{K}_{0.8} \mathrm{Mg}_{0.4} \mathrm{Ti}_{1.6} \mathrm{O}_{4}$ (KMTO) products, namely KMTO platelets, boards, and bars obtained at three sets of optimum conditions $(\alpha=0.7,1.5$, and 2.5; $\left.\beta=0.75 ; \mathrm{T}=1050{ }^{\circ} \mathrm{C}, \mathrm{t}=4 \mathrm{~h}\right)$, were discussed in detail.

\subsection{Preparation of Sodium Iron Titanates (NFTO)}

Sodium iron titanates were produced by the same procedure as described in the preparation of KMTO. The starting materials of $\mathrm{Na}_{2} \mathrm{CO}_{3}$ and $\mathrm{FeTiO}_{3}$, with or without $\mathrm{Fe}_{2} \mathrm{O}_{3}$, were mixed with $\mathrm{KCl}-\mathrm{NaCl}$ molten salt $(\beta=0,0.25,0.5,0.75$, and 1$)$ at a certain molar ratio $(\alpha=2,4$, and 6$)$. The mixture was calcined at $600,700,800,900$, and $1000{ }^{\circ} \mathrm{C}$ for 2,4 , or $6 \mathrm{~h}$ for the procedure optimization. Two kinds of NFTO products, $\mathrm{NaFeTiO}_{4}$ needles and $\mathrm{Na}_{0.75} \mathrm{Fe}_{0.75} \mathrm{Ti}_{0.25} \mathrm{O}_{2}$ platelets, were obtained at two sets of optimum conditions. Without $\mathrm{Fe}_{2} \mathrm{O}_{3}$ as the Fe source, $\mathrm{NaFeTiO}_{4}$ needles were prepared at the condition of Na:Fe:Ti $=1.3: 1: 1, \alpha=4, \beta=0, \mathrm{~T}=90{ }^{\circ} \mathrm{C}$, and $\mathrm{t}=4 \mathrm{~h}$. With the presence of $\mathrm{Fe}_{2} \mathrm{O}_{3}$, $\mathrm{Na}_{0.75} \mathrm{Fe}_{0.75} \mathrm{Ti}_{0.25} \mathrm{O}_{2}$ platelets were obtained during the condition of $\mathrm{Na}: \mathrm{Fe}: \mathrm{Ti}=3.3: 2.2: 1, \alpha=4, \beta=0$, $\mathrm{T}=1000^{\circ} \mathrm{C}$, and $\mathrm{t}=4 \mathrm{~h}$.

\subsection{Characterizations}

The crystalline phase of samples were examined with X-ray diffraction (XRD) by using a D8-Advance, Bruker AXS diffractometer $(\mathrm{Cu}-\mathrm{K} \alpha$ radiation, $\lambda=1.5418 \AA$ ) in the continuous scan mode over $5-70^{\circ}(2 \theta)$ with a scan rate of $0.3^{\circ} / \mathrm{s}$, operating at $40 \mathrm{kV}$ and $40 \mathrm{~mA}$. The morphology and microstructure of samples were characterized by field-emission scanning electron microscopy (FESEM, HITACHI S-4800, Hitachi, Tokyo, Japan) equipped with energy-dispersive X-ray spectroscopy (EDS). Thermogravimetric analysis (TGA) was performed on a NETZSCH 449 STA thermogravimetric analyzer (Netzsch, Sabre, Germany). The samples were heated in $\mathrm{N}_{2}$ atmosphere from 30 to $1100{ }^{\circ} \mathrm{C}$ at a heating rate of $10^{\circ} \mathrm{C} \cdot \mathrm{min}^{-1}$. 


\section{Results and Discussion}

\subsection{Synthesis of KMTO with Different Morphologies}

Figures 1 and 2 show the SEM images and XRD patterns of the KMTO samples prepared at different molar ratios of the molten salt $\mathrm{KCl}-\mathrm{NaCl}$ to the raw materials $(\alpha=0.7,1.5$, and 2.5) after calcination at $1050^{\circ} \mathrm{C}$ for $4 \mathrm{~h}$. The morphologies of KMTO products are shaped like platelets $(\alpha=0.7$, Figure 1a1,a2), boards ( $\alpha=1.5$, Figure $1 \mathrm{~b} 1, \mathrm{~b} 2)$, and bars $(\alpha=2.5$, Figure $1 \mathrm{c} 1, \mathrm{c} 2)$, respectively. As shown in Figure 2, the major phase of all the three differently shaped products exhibit the XRD patterns belonging to $\mathrm{K}_{0.8} \mathrm{M}_{\mathrm{g} 0.4} \mathrm{Ti}_{1.6} \mathrm{O}_{4}$ (PDF\#35-0046). A very small amount of impurity peaks of hydrated potassium tianium hydrogen oxide hydrate $\left(\mathrm{K}_{0.5} \mathrm{H}_{1.5} \mathrm{Ti}_{4} \mathrm{O}_{9} \cdot 0.6 \mathrm{H}_{2} \mathrm{O}\right)$ is also observable in KMTO boards and bars (Figure $2 \mathrm{c}, \mathrm{d}$ ). This impurity phase may be due to the dissolution of $\mathrm{K}^{+}$and $\mathrm{Mg}^{+}$when the products were washed by DI water. The relative peak intensity of three samples differs from that of the standard XRD pattern and the product synthesized without the presence of molten salts $(\alpha=0$, Figure 2a). The deviation of the peak intensity is caused by the preferential growth of samples. The elemental analysis from EDS is consistent with XRD, see Supplementary Figure S1. Figures S2 and S3 show the products prepared at different reaction temperatures $\left(750,850\right.$, and $\left.950^{\circ} \mathrm{C}\right)$ and different reaction durations $(2,4$, and $6 \mathrm{~h})$. The pure phase KMTO obtained at $1050{ }^{\circ} \mathrm{C}$ for $4 \mathrm{~h}$ have obviously better morphology control.

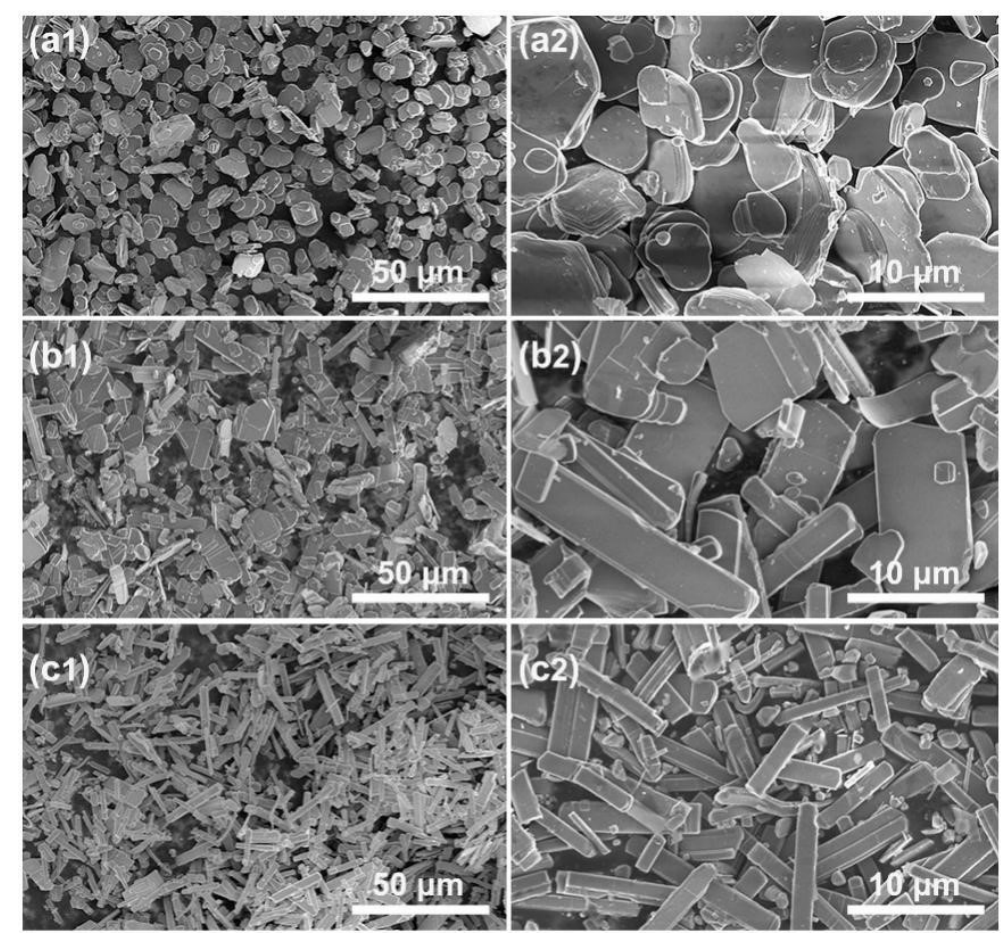

Figure 1. SEM images of three differently shaped KMTO products prepared at $1050{ }^{\circ} \mathrm{C}$ for $4 \mathrm{~h}$ with different molar ratios of the molten salt to the raw materials: $(\mathbf{a 1}, \mathbf{a 2})$ platelets, $\alpha=0.7, \beta=0.75 ;(\mathbf{b} 1, \mathbf{b} 2)$ boards, $\alpha=1.5, \beta=0.75$; and (c1,c2) bars $\alpha=2.5, \beta=0.75$. 


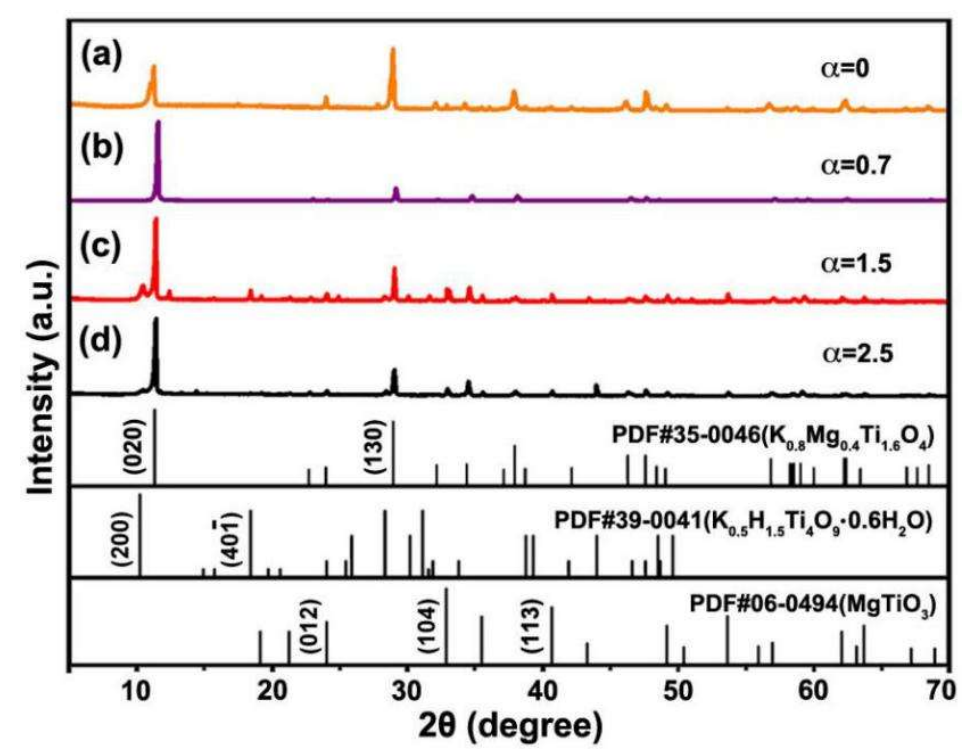

Figure 2. X-ray diffraction (XRD) patterns of three differently shaped KMTO products prepared at $1050{ }^{\circ} \mathrm{C}$ for $4 \mathrm{~h}$ with different molar ratios of the molten salt to the raw materials: (a) Without molten salt; (b) platelets, $\alpha=0.7, \beta=0.75$; (c) boards, $\alpha=1.5, \beta=0.75$; and (d) bars $\alpha=2.5, \beta=0.75$.

The growth mechanism of the KMTO platelets, boards, and bars are proposed as depicted in Figure 3 , based on the melting point of the molten salt $\left(675^{\circ} \mathrm{C}\right.$ for $\left.\beta=0.75\right)$, calculations on the thermodynamics of the reactions between sodium and potassium cations, and analyses using SEM (Figure S2), XRD (Figure S4), and TG-DSC (Figure S5) on the intermediate products during the entire heating process. As the calcination temperature increases, $4 \mathrm{MgCO}_{3} \cdot \mathrm{Mg}(\mathrm{OH})_{2} \cdot 5 \mathrm{H}_{2} \mathrm{O}$ first loses hydration water and then decomposes to $\mathrm{MgO}$ and $\mathrm{CO}_{2}$. Upon the dissolution of $\mathrm{K}_{2} \mathrm{CO}_{3}$ and $\mathrm{MgO}$ in the $\mathrm{NaCl}-\mathrm{KCl}$ molten salt, $\mathrm{K}^{+}$and $\mathrm{Mg}^{2+}$ ions diffuse at different rates in the liquid phase, approaching the dispersed $\mathrm{TiO}_{2}$ particles. When $\alpha=0.7, \mathrm{KMTO}$ particles are directly formed and then gradually evolve to crystalline platelets as the temperature reaches $1050{ }^{\circ} \mathrm{C}$. When $\alpha \geq 1.5$, with abundant $\mathrm{Na}^{+}$in the system, low-melting intermediate phase $\mathrm{Na}_{8} \mathrm{Ti}_{5} \mathrm{O}_{14}$ (melting point $965 \sim 985{ }^{\circ} \mathrm{C}$ ) is formed first and then it interacts with $\mathrm{Mg}^{2+}$ and $\mathrm{K}^{+}$in the melt to form more stable NMTO bars (melting point $1100{ }^{\circ} \mathrm{C}$ ). Based on the thermodynamic calculation, the ion exchange from $\mathrm{Na}^{+}$to $\mathrm{K}^{+}$will spontaneously occur when the system temperature is above $675^{\circ} \mathrm{C}$. So as the temperature continues to increase, $\mathrm{Na}^{+}$in NMTO exchanges with $\mathrm{K}^{+}$from the molten salt, resulting in a more stable high melting KMTO phase (melting point $1300{ }^{\circ} \mathrm{C}$ ) which retains a long strip shape. The morphology and crystalline phase of the intermediate NMTO phase were confirmed by characterizing the samples rapidly annealed at 750, 850, and $950{ }^{\circ} \mathrm{C}$ by using SEM and XRD (Figures S2 and S4). 


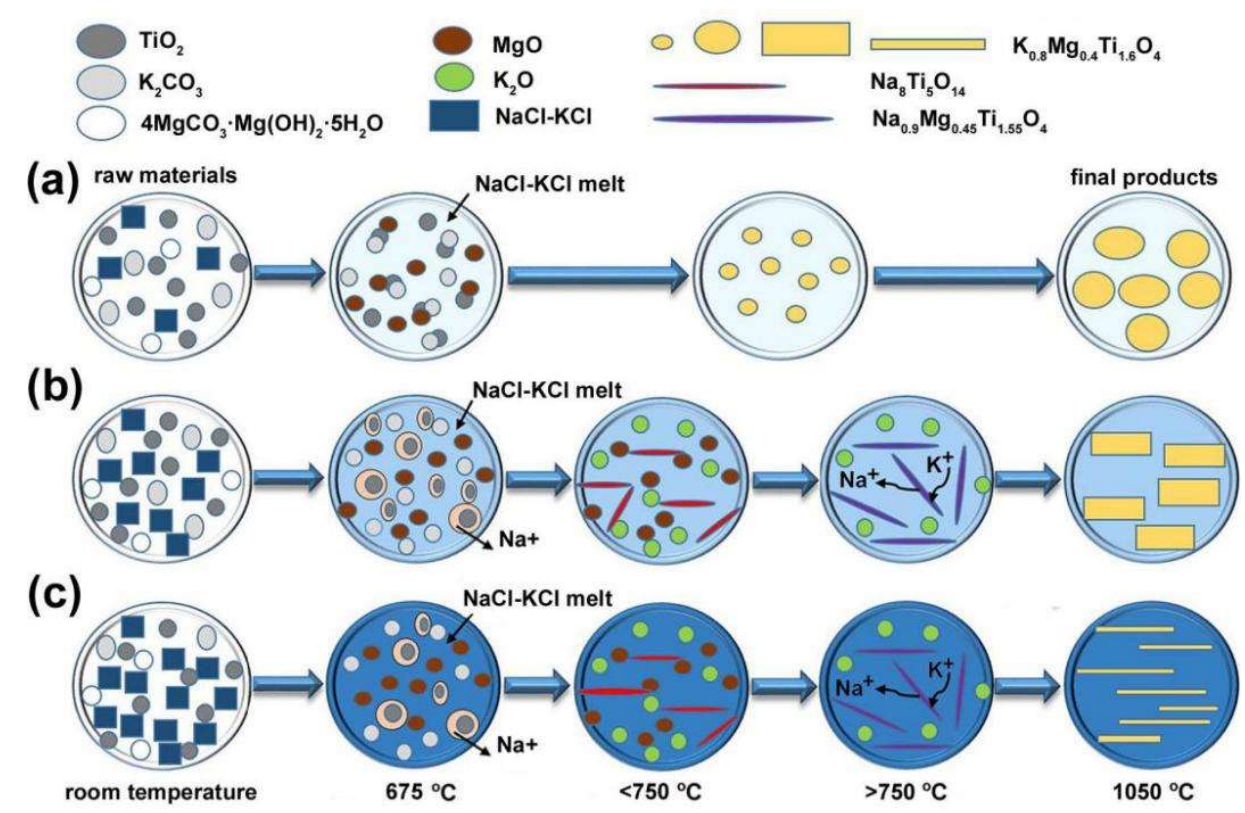

Figure 3. Schematic diagram of the synthesis mechanism of KMTO with different morphologies. (a) KMTO platelets, (b) KMTO boards, and (c) KMTO bars.

This kind of morphology control cannot be obtained by using $\mathrm{KCl}(\beta=1)$ or $\mathrm{NaCl}(\beta=0)$ alone as the molten salt. Figures 4 and 5 show the XRD patterns and SEM images of the samples prepared at different mole ratios of the molten salt to the raw materials $(\alpha=0.5,2$, and 6$)$ after calcination at $1050{ }^{\circ} \mathrm{C}$ for $4 \mathrm{~h}$. When using $\mathrm{KCl}$ as the molten salt $(\beta=1)$, all three samples are pure KMTO phase (Figure 4a1-a3). As the molar ratio $\alpha$ increases from 0.5 to 2 and 6 , the relative peak intensity changes. However, all three samples have the platelet morphology of several micrometers (Figure 5a1-a3), indicating that single $\mathrm{KCl}$ molten salt cannot cause the platelet-board-bar morphology evolution as $\mathrm{KCl}-\mathrm{NaCl}$. When using single $\mathrm{NaCl}$ as molten salt $(\beta=0)$, a new phase of sodium magnesium titanate $\left(\mathrm{Na}_{0.9} \mathrm{Mg}_{0.45} \mathrm{Ti}_{1.55} \mathrm{O}_{4}\right)$ appears and the product becomes slender as the amount of $\mathrm{NaCl}$ in the molten salt increases. At $\alpha=0.5$, the product is a mixture of KMTO particles and NMTO bars (Figures $4 \mathrm{~b} 1$ and $5 \mathrm{~b} 1$ ). When $\alpha$ increases to 2, the KMTO phase disappears and the product becomes pure NMTO rods (Figures $4 \mathrm{~b} 2$ and $5 \mathrm{~b} 2$ ), indicating that $\mathrm{NaCl}$ in the molten salt provided $\mathrm{Na}^{+}$to participate in the crystal growth reaction. When $\alpha$ increases to six, the product is long NMTO whiskers (Figures $4 \mathrm{~b} 3$ and 5b3). Although the equilibrium constant for $\mathrm{NaCl}(l)+\mathrm{K}^{+}(s) \rightarrow \mathrm{Na}^{+}(s)+\mathrm{KCl}(l)$ is 1 [16], the $\mathrm{K}^{+}$ions in the layer structured KMTO can still be displaced by $\mathrm{Na}^{+}$via ion exchange when the concentration of surrounding $\mathrm{Na}^{+}$ions is sufficiently large. The above experimental results indicate that the molten salt does not only provide a liquid phase environment for reactions, however the cations may also participate in reactions and strongly affect the growth of crystalline products. 


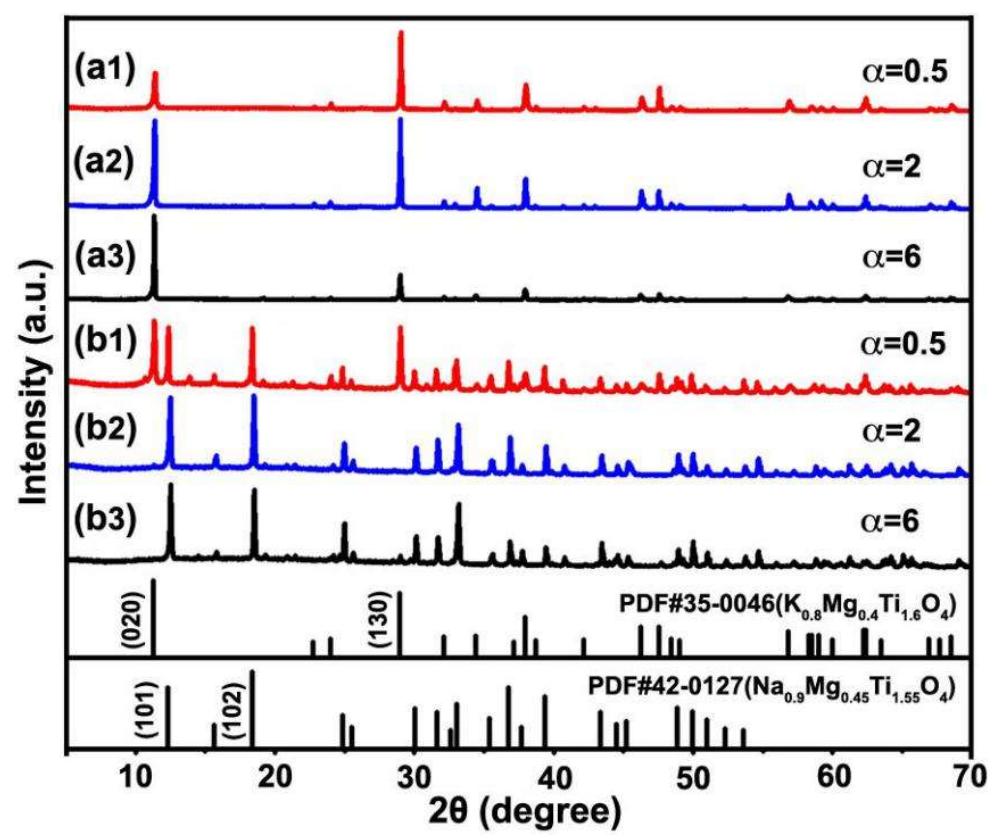

Figure 4. XRD patterns of samples prepared at $1050{ }^{\circ} \mathrm{C}$ for $4 \mathrm{~h}$ while using $(\mathbf{a} 1-\mathbf{a} 3) \mathrm{KCl}(\beta=1)$ or (b1-b3) $\mathrm{NaCl}(\beta=0)$ alone as the molten salt. $(\mathbf{a} 1, \mathbf{b} 1): \alpha=0.5,(\mathbf{a} 2, \mathbf{b} 2): \alpha=2$, and $(\mathbf{a} 3, \mathbf{b} 3): \alpha=6$.

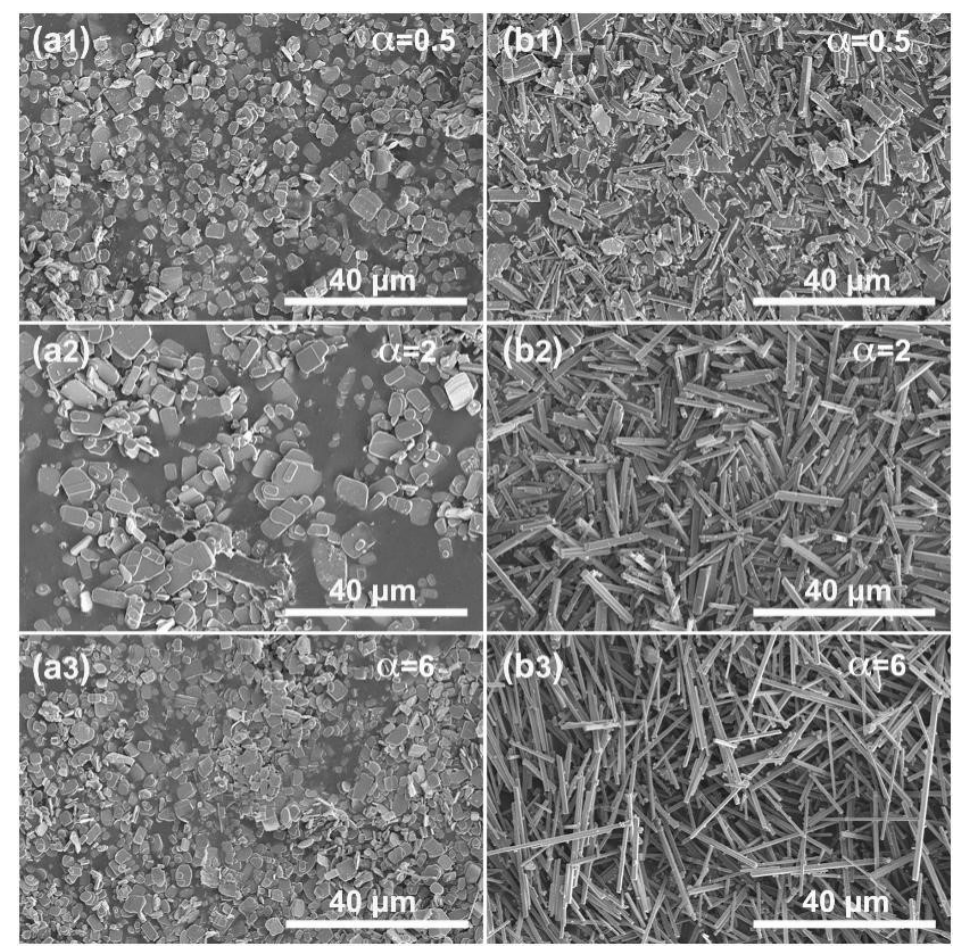

Figure 5. SEM images of the samples prepared at $1050{ }^{\circ} \mathrm{C}$ for $4 \mathrm{~h}$ while using (a1-a3) $\mathrm{KCl}(\beta=1)$ or (b1-b3) $\mathrm{NaCl}(\beta=0)$ alone as the molten salt. $(\mathbf{a} 1, \mathbf{b} 1): \alpha=0.5,(\mathbf{a} 2, \mathbf{b} 2): \alpha=2$, and $(\mathbf{a} 3, \mathbf{b} 3): \alpha=6$.

\subsection{Synthesis of NFTO with Different Morphologies}

Figures 6 and 7 show the XRD pattern and SEM images of the NFTO samples synthesized while using $\mathrm{NaCl}$ as the molten salt. At the condition of Na:Fe:Ti = 1.3:1:1 and Na:Fe:Ti = 3.3:2.2:1, the XRD patterns of the products can be assigned to $\mathrm{NaFeTiO}_{4}\left(\mathrm{PDF} \# 33-1255\right.$, Figure 6a) and $\mathrm{Na}_{0.75} \mathrm{Fe}_{0.75} \mathrm{Ti}_{0.25} \mathrm{O}_{2}$ (PDF\#25-0877, Figure 6b), respectively. None of the noticeable peaks belong to the unreacted reactants $\left(\mathrm{Na}_{2} \mathrm{CO}_{3}\right)$ or intermediate phase $\left(\mathrm{Fe}_{2} \mathrm{O}_{3}\right)$, indicating that the starting materials have been completely 
transformed to products at appropriate annealing temperatures $\left(\mathrm{NaFeTiO}_{4}, 900{ }^{\circ} \mathrm{C} ; \mathrm{Na}_{0.75} \mathrm{Fe}_{0.75} \mathrm{Ti}_{0.25} \mathrm{O}_{2}\right.$ ， $1000{ }^{\circ} \mathrm{C}$ ). The chemical composition of products is also confirmed by EDS analyses (Figure S6). As shown in Figure 7, $\mathrm{NaFeTiO}_{4}$ is in the shape of needles with the length of 20-50 $\mu \mathrm{m}$ and diameter of $0.5-2 \mu \mathrm{m}$, while $\mathrm{Na}_{0.75} \mathrm{Fe}_{0.75} \mathrm{Ti}_{0.25} \mathrm{O}_{2}$ has the platelet shape with the size range of $5-20 \mu \mathrm{m}$. The products show the best morphology when the molar ratio of $\mathrm{NaCl}$ to the raw materials is $\alpha=4$ (Figure 8). The influence of the ratio of reactants on the product was also investigated and the condition of $\mathrm{Na}: \mathrm{Fe}: \mathrm{Ti}=3.3: 2.2: 1$ shows the pure phase $\mathrm{Na}_{0.75} \mathrm{Fe}_{0.75} \mathrm{Ti}_{0.25} \mathrm{O}_{2}$ with relatively uniform morphology (Figure S7). Figures S8 and S9 show the products prepared at different reaction temperatures (600, $700,800,900$, and $\left.1000{ }^{\circ} \mathrm{C}\right)$ and different reaction durations $(2,4$, and $6 \mathrm{~h}) . \mathrm{NaFeTiO}_{4}$ needles with best morphology were obtained at $900{ }^{\circ} \mathrm{C}$ for $4 \mathrm{~h}$ and $\mathrm{Na}_{0.75} \mathrm{Fe}_{0.75} \mathrm{Ti}_{0.25} \mathrm{O}_{2}$ platelets were obtained at $1000{ }^{\circ} \mathrm{C}$ for $4 \mathrm{~h}$.

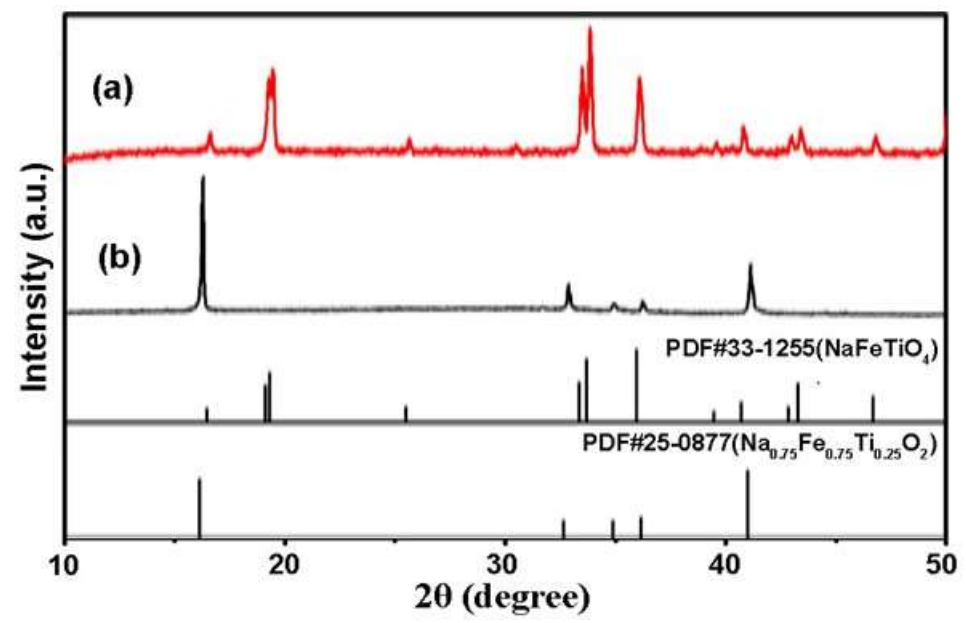

Figure 6. XRD patterns of (a) $\mathrm{NaFeTiO}_{4}$ needles (formed at $\alpha=4, \beta=0, \mathrm{~T}=900{ }^{\circ} \mathrm{C}$, and $\mathrm{t}=4 \mathrm{~h}$ ), and (b) $\mathrm{Na}_{0.75} \mathrm{Fe}_{0.75} \mathrm{Ti}_{0.25} \mathrm{O}_{2}$ platelets (formed at $\alpha=4, \beta=0, \mathrm{~T}=1000{ }^{\circ} \mathrm{C}$, and $\mathrm{t}=4 \mathrm{~h}$ ).

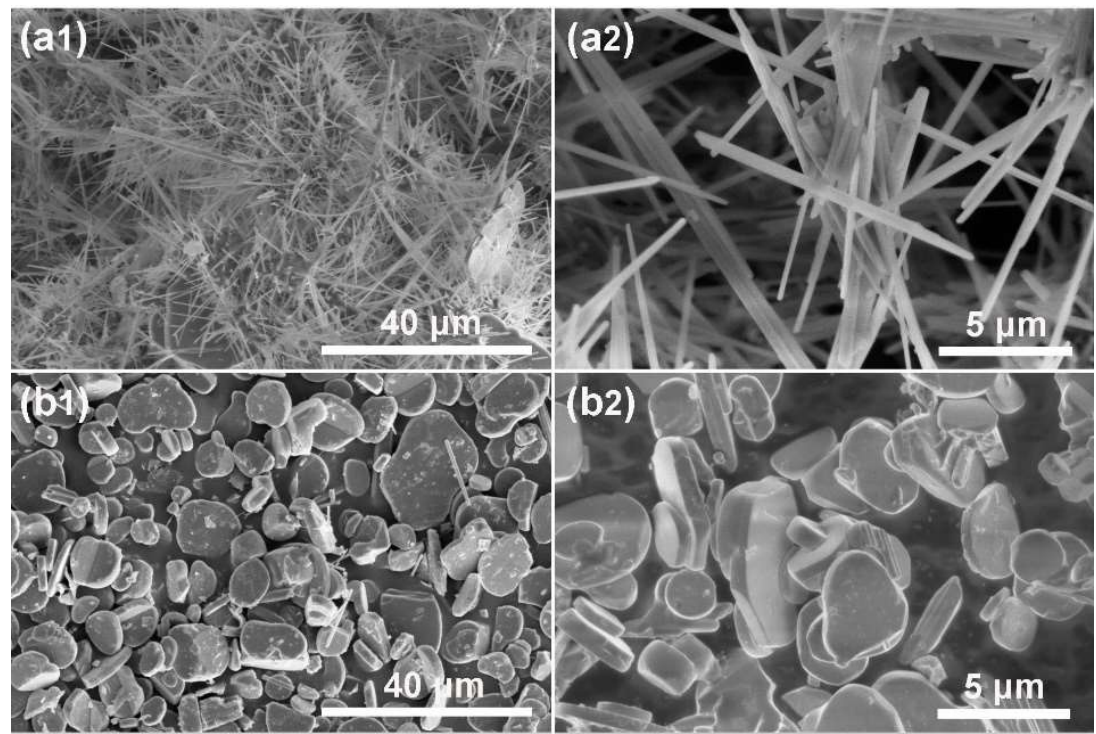

Figure 7. SEM images of (a1,a2) $\mathrm{NaFeTiO}_{4}$ needles (formed at $\alpha=4, \beta=0, \mathrm{~T}=900{ }^{\circ} \mathrm{C}$, and $\mathrm{t}=4 \mathrm{~h}$ ), and $(\mathbf{b} 1, \mathbf{b} 2) \mathrm{Na}_{0.75} \mathrm{Fe}_{0.75} \mathrm{Ti}_{0.25} \mathrm{O}_{2}$ platelets (formed at $\alpha=4, \beta=0, \mathrm{~T}=1000{ }^{\circ} \mathrm{C}$, and $\mathrm{t}=4 \mathrm{~h}$ ). 

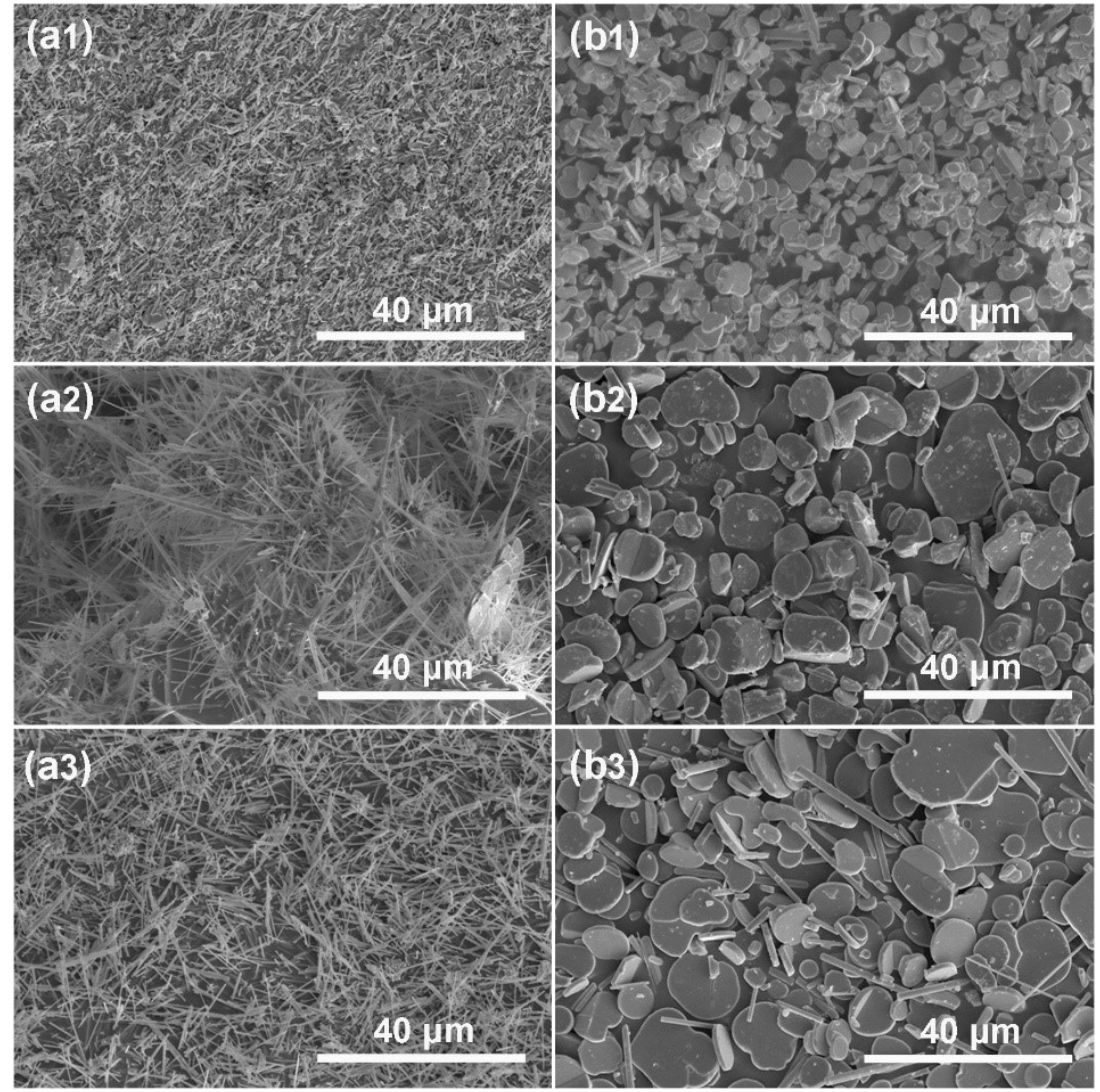

Figure 8. SEM images of (a1-a3) $\mathrm{NaFeTiO}_{4}$ needles and (b1-b3) $\mathrm{Na}_{0.75} \mathrm{Fe}_{0.75} \mathrm{Ti}_{0.25} \mathrm{O}_{2}$ platelets while using $\mathrm{NaCl}$ alone as the molten salt. $(\mathbf{a} 1, \mathbf{b} 1) \alpha=2,(\mathbf{a} 2, \mathbf{b} 2) \alpha=4$, and $(\mathbf{a} 3, \mathbf{b} 3) \alpha=6 ; \beta=0$.

The growth mechanism of NFTO is proposed as depicted in Figure 9, based on the analyses using SEM (Figure S8), XRD (Figure S10), and TG-DSC (Figure S11). As the calcination temperature increases, free water in the raw materials gets released and $\mathrm{Na}_{2} \mathrm{CO}_{3}$ decomposes to $\mathrm{Na}_{2} \mathrm{O}$ and $\mathrm{CO}_{2}$ below $700{ }^{\circ} \mathrm{C}$. After $\mathrm{FeTiO}_{3}$ is completely converted to $\mathrm{Fe}_{2} \mathrm{O}_{3}$ and $\mathrm{Fe}_{2} \mathrm{Ti}_{3} \mathrm{O}_{9}$ around $620{ }^{\circ} \mathrm{C}$, the reaction system changes from $\mathrm{Na}_{2} \mathrm{CO}_{3}-\mathrm{FeTiO}_{3}$ to $\mathrm{Na}_{2} \mathrm{O}-\mathrm{Fe}_{2} \mathrm{O}_{3}-\mathrm{Fe}_{2} \mathrm{Ti}_{3} \mathrm{O}_{9}$. The $\mathrm{NaFeTiO}_{4}$ phase starts to appear after $700{ }^{\circ} \mathrm{C}$. The $\mathrm{Fe}_{2} \mathrm{O}_{3}$ and $\mathrm{Fe}_{2} \mathrm{Ti}_{3} \mathrm{O}_{9}$ were completely consumed at $900{ }^{\circ} \mathrm{C}$. The product obtained at $900{ }^{\circ} \mathrm{C}$ exhibits the best needle-like morphology and a relatively narrow size dispersion. The average diameter and length of the as-prepared $\mathrm{NaFeTiO}_{4}$ needles are in the range of $0.5-2 \mu \mathrm{m}$ and $20-50 \mu \mathrm{m}$, respectively. At $1000{ }^{\circ} \mathrm{C}$, part of $\mathrm{NaFeTiO}_{4}$ starts to break into small pieces. $\mathrm{Fe}_{2} \mathrm{O}_{3}$ was added in the starting materials to increase the Fe content. $\mathrm{NaFeTiO}_{4}$ with low crystallinity forms at $700{ }^{\circ} \mathrm{C}$. With sufficient Fe source, $\mathrm{Na}_{0.75} \mathrm{Fe}_{0.75} \mathrm{Ti}_{0.25} \mathrm{O}_{2}$ platelets start to appear at $800{ }^{\circ} \mathrm{C}$. Thus, $\mathrm{Na}_{0.75} \mathrm{Fe}_{0.75} \mathrm{Ti}_{0.25} \mathrm{O}_{2}$ platelets and a small amount of $\mathrm{NaFeTiO}_{4}$ rods are both present in products from $800-900{ }^{\circ} \mathrm{C}$. At $1000{ }^{\circ} \mathrm{C}, \mathrm{NaFeTiO}_{4}$ phase is disappeared and pure phase $\mathrm{Na}_{0.75} \mathrm{Fe}_{0.75} \mathrm{Ti}_{0.25} \mathrm{O}_{2}$ platelets are obtained.

To investigate the influence of molten salt type on the growth of NFTO, $\mathrm{KCl}-\mathrm{NaCl}$ composite molten salt with different ratios were used for reactions. Figures 10 and 11 show the XRD patterns and SEM images while using $\mathrm{KCl}-\mathrm{NaCl}$ as the composite molten salt and $\alpha$ is fixed at 4 . When $\beta$ is below 0.5 , only the $\mathrm{NaFeTiO}_{4}$ phase is detectable. At $\beta=0.25$, the product has both rod-like and platelet shapes. At $\beta=0.5$, the rods are apparently larger in size, accompanied with randomly shaped particles. While $\beta$ is 0.75 , the product is a mixture of $\mathrm{NaFeTiO}_{4}$ and $\mathrm{K}_{2.3} \mathrm{Fe}_{2.3} \mathrm{Ti}_{5.7} \mathrm{O}_{16}$ and the product contains both big rods and random particles. When the $\mathrm{KCl}$ content reaches $100 \%(\beta=1)$, pure phase $\mathrm{K}_{2.3} \mathrm{Fe}_{2.3} \mathrm{Ti}_{5.7} \mathrm{O}_{16}$ is observed. The morphology changes to a mixture of large plates and small particles. Hence, the results indicate that $\mathrm{KCl}$ in the molten salt can participate in the crystal growth of NFTO and should be avoided for obtaining pure phase NFTO. 


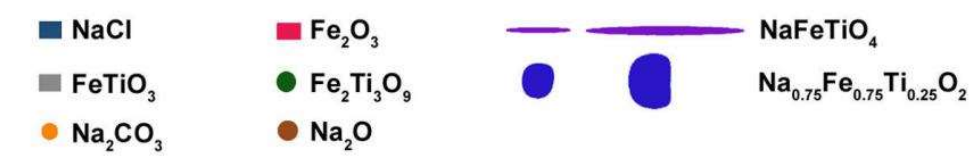

(a)

raw materials



(b)


room temperature

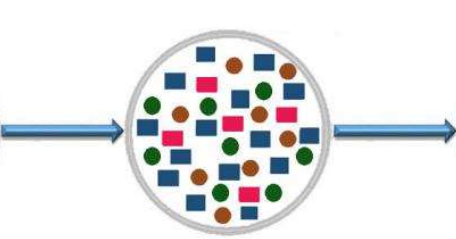

$620^{\circ} \mathrm{C}$

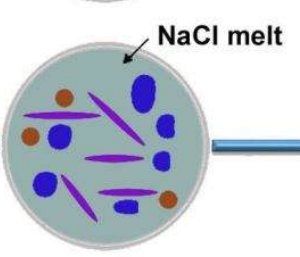

$801^{\circ} \mathrm{C}$

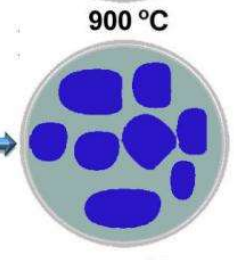

$1000^{\circ} \mathrm{C}$

Figure 9. Schematic diagram of the synthesis mechanism of NFTO with different morphologies. (a) $\mathrm{NaFeTiO}_{3}$ needles, and (b) $\mathrm{Na}_{0.75} \mathrm{Fe}_{0.75} \mathrm{Ti}_{0.25} \mathrm{O}_{2}$ platelets.

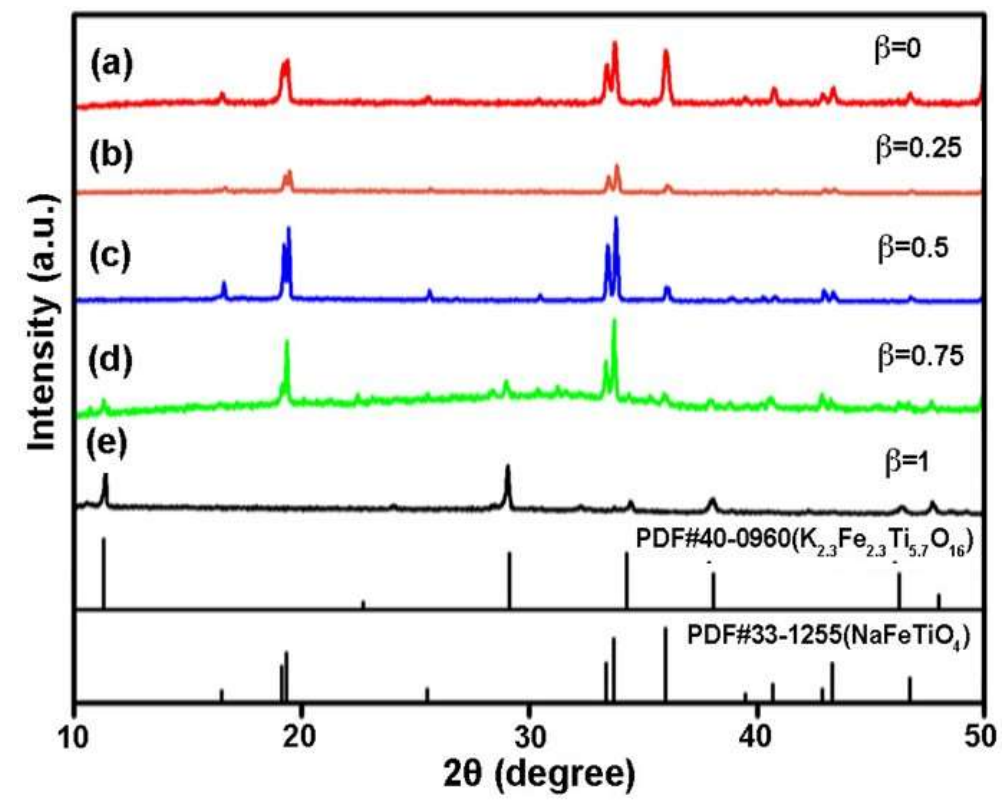

Figure 10. XRD patterns of samples obtained while using $\mathrm{KCl}-\mathrm{NaCl}$ as molten salt at the condition of $\mathrm{Na}: \mathrm{Fe}: \mathrm{Ti}=1.3: 1: 1, \alpha=4, \mathrm{~T}=900{ }^{\circ} \mathrm{C}$, and $\mathrm{t}=4 \mathrm{~h}$. (a) $\beta=0,(\mathbf{b}) \beta=0.25$, (c) $\beta=0.5$, (d) $\beta=0.75$, and (e) $\beta=1$. 

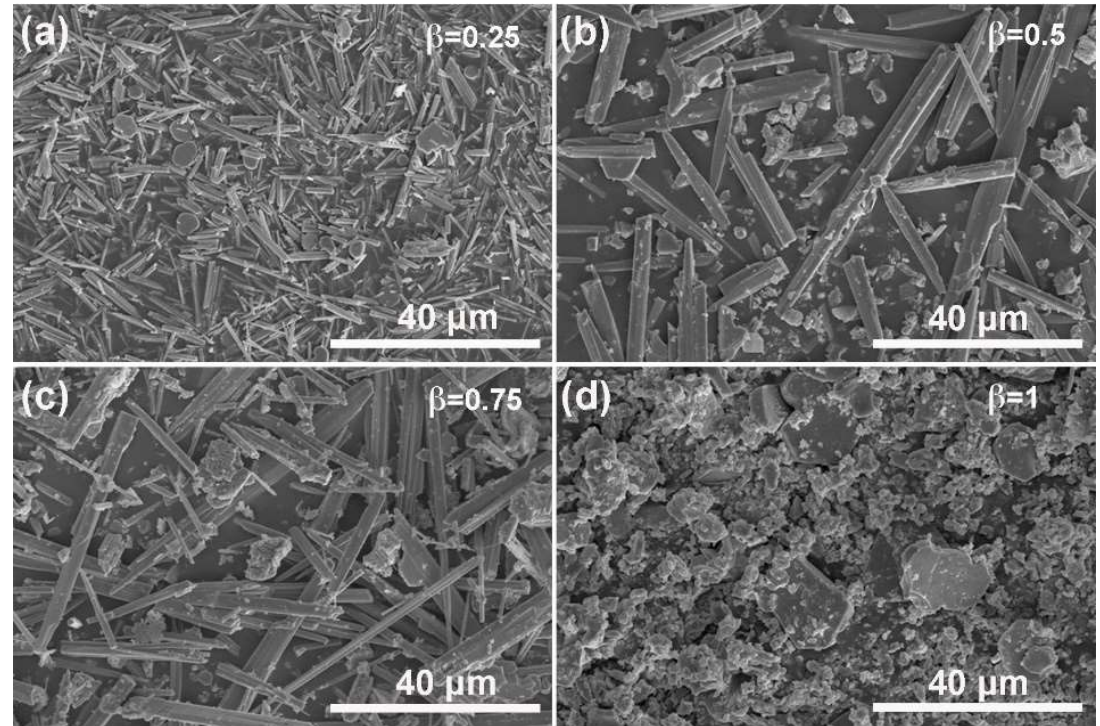

Figure 11. SEM images of samples obtained while using $\mathrm{KCl}-\mathrm{NaCl}$ as molten salt at the condition of $\mathrm{Na}: \mathrm{Fe}: \mathrm{Ti}=1.3: 1: 1, \alpha=4, \mathrm{~T}=900{ }^{\circ} \mathrm{C}$, and $\mathrm{t}=4 \mathrm{~h}$. (a) $\beta=0.25,(\mathbf{b}) \beta=0.5$, (c) $\beta=0.75$, and (d) $\beta=1$.

\section{Conclusions}

We have prepared a series of quaternary KMTO and NFTO titanates by using the molten salt synthesis method. The molar ratio of molten salt is critical to the composition and morphology of products. The $\mathrm{KCl}-\mathrm{NaCl}$ molten salt is preferred for growing KMTO. When $\alpha=0.7,1.5$, and $2.5(\beta=0.75), \mathrm{K}_{0.8} \mathrm{Mg}_{0.8} \mathrm{Ti}_{1.6} \mathrm{O}_{4}$ platelets, $\mathrm{K}_{0.8} \mathrm{Mg}_{0.8} \mathrm{Ti}_{1.6} \mathrm{O}_{4}$ boards, and $\mathrm{K}_{0.8} \mathrm{Mg}_{0.8} \mathrm{Ti}_{1.6} \mathrm{O}_{4}$ bars were obtained, respectively, after calcination at $1050{ }^{\circ} \mathrm{C}$ for $4 \mathrm{~h}$. NMTO was prepared by using $\mathrm{NaCl}$ alone as the molten salt. When $\alpha=4$ and $\beta=0, \mathrm{NaFeTiO}_{4}$ needles and $\mathrm{Na}_{0.75} \mathrm{Fe}_{0.75} \mathrm{Ti}_{0.25} \mathrm{O}_{2}$ platelets were obtained. The calcination temperatures were 900 and $1000{ }^{\circ} \mathrm{C}$, respectively. The well-controlled morphology is useful for practical applications.

Supplementary Materials: The following are available online at http://www.mdpi.com/1996-1944/12/10/1577/s1, Figure S1: EDS analyses of (a) $\mathrm{K}_{0.8} \mathrm{Mg}_{0.4} \mathrm{Ti}_{1.6} \mathrm{O}_{4}$ platelets, (b) $\mathrm{K}_{0.8} \mathrm{Mg}_{0.4} \mathrm{Ti}_{1.6} \mathrm{O}_{4}$ boards, and (c) $\mathrm{K}_{0.8} \mathrm{Mg}_{0.4} \mathrm{Ti}_{1.6} \mathrm{O}_{4}$ bars, Figure S2: SEM images of the products obtained after annealing the starting materials for (a1-a3) $\mathrm{K}_{0.8} \mathrm{M}_{\mathrm{g} 0.4} \mathrm{Ti}_{1.6} \mathrm{O}_{4}$ platelets, (b1-b3) $\mathrm{K}_{0.8} \mathrm{M}_{\mathrm{g} 0.4} \mathrm{Ti}_{1.6} \mathrm{O}_{4}$ boards, and (c1-c3) $\mathrm{K}_{0.8} \mathrm{M}_{\mathrm{g} 0.4} \mathrm{Ti}_{1.6} \mathrm{O}_{4}$ bars at different temperatures. (a1, b1, c1) $750{ }^{\circ} \mathrm{C},(\mathbf{a} 2, \mathbf{b} 2, \mathbf{c 2}) 850{ }^{\circ} \mathrm{C}$, and $(\mathbf{a} 3, \mathbf{b} 3, \mathbf{c} 3) 950{ }^{\circ} \mathrm{C}$, Figure S3. SEM images of the products obtained after annealing the starting materials for (a1-a3) $\mathrm{K} 0.8 \mathrm{Mg} 0.4 \mathrm{Ti1} .6 \mathrm{O} 4$ platelets, (b1-b3) K0.8Mg0.4Ti1.6O4 boards, and (c1-c3) K0.8Mg0.4Ti1.6O4 bars at different times. (a1, b1, c1) 2 h, (a2, b2, c2) 4 h, and (a3, b3, c3) 6 h, Figure S4: XRD patterns of the products obtained after annealing the starting materials for (a1-a4) $\mathrm{K}_{0.8} \mathrm{M}_{\mathrm{g} 0.4} \mathrm{Ti}_{1.6} \mathrm{O}_{4}$ platelets, (b1-b4) $\mathrm{K}_{0.8} \mathrm{M}_{\mathrm{g} 0.4} \mathrm{Ti}_{1.6} \mathrm{O}_{4}$ boards, and (c1-c4) $\mathrm{K}_{0.8} \mathrm{M}_{\mathrm{g} 0.4} \mathrm{Ti}_{1.6} \mathrm{O}_{4}$ bars at different temperatures. (a1, b1, c1) $750{ }^{\circ} \mathrm{C}$, $(\mathbf{a} 2, \mathbf{b} 2, \mathbf{c 2}) 850{ }^{\circ} \mathrm{C},(\mathbf{a} 3, \mathbf{b 3}, \mathbf{c} 3) 950{ }^{\circ} \mathrm{C}$, and $(\mathbf{a} 4, \mathbf{b} 4, \mathbf{c} 4) 1050{ }^{\circ} \mathrm{C}$, Figure S5: TG-DSC plots of (a) $\mathrm{K}_{0.8} \mathrm{M}_{\mathrm{g} 0.4} \mathrm{Ti}_{1.6} \mathrm{O}_{4}$ platelets, (b) $\mathrm{K}_{0.8} \mathrm{M}_{\mathrm{g} 0.4} \mathrm{Ti}_{1.6} \mathrm{O}_{4}$ boards, and (c) $\mathrm{K}_{0.8} \mathrm{M}_{\mathrm{g} 0.4} \mathrm{Ti}_{1.6} \mathrm{O}_{4}$ bars, Figure S6: EDS analyses of (a) $\mathrm{K}_{0.8} \mathrm{M}_{\mathrm{g} 0.4} \mathrm{Ti}_{1.6} \mathrm{O}_{4}$ platelets, (b) $\mathrm{K}_{0.8} \mathrm{M}_{\mathrm{g} 0.4} \mathrm{Ti}_{1.6} \mathrm{O}_{4}$ boards, and (c) $\mathrm{K}_{0.8} \mathrm{M}_{\mathrm{g} 0.4} \mathrm{Ti}_{1.6} \mathrm{O}_{4}$ bars, Figure S7: XRD patterns of the products prepared with different ratio of reactants for $\mathrm{Na}_{0.75} \mathrm{Fe}_{0.75} \mathrm{Ti}_{0.25} \mathrm{O}_{2} . \mathrm{Na}: \mathrm{Fe}: \mathrm{Ti}=(\mathbf{a})$ 3.3:1.5:1, (b) 3.3:2.0:1, (c) 3.3:2.5:1, (d) 3.3:3.0:1, and (e) 3.3: 3.5:1, Figure S8: SEM images of the products obtained after annealing the starting materials for (a1-a3) $\mathrm{NaFeTiO}_{4}$ and (b1-b3) $\mathrm{Na}_{0.75} \mathrm{Fe}_{0.75} \mathrm{Ti}_{0.25} \mathrm{O}_{2}$ at different times. (a1, b1) $600{ }^{\circ} \mathrm{C},(\mathbf{a} 2, \mathbf{b} 2) 700{ }^{\circ} \mathrm{C},(\mathbf{a} 3, \mathbf{b 3})$ $800^{\circ} \mathrm{C},(\mathbf{a} 4, \mathbf{b} 4) 900{ }^{\circ} \mathrm{C}$, and $(\mathbf{a} 5, \mathbf{b} 5) 1000^{\circ} \mathrm{C}$, Figure S9: SEM images of the products obtained after annealing the starting materials for (a1-a3) NaFeTiO4 and (b1-b3) Na0.75Fe0.75Ti0.25O2 at different times. (a1, b1) 2 h, (a2, b2) $4 \mathrm{~h}$, and $(\mathbf{a} 3, \mathbf{b 3}) 6 \mathrm{~h}$, Figure S10: XRD patterns of the products obtained after annealing the starting materials for (a1-a5) NaFeTiO4 and (b1-b5) Na0.75Fe0.75Ti0.25O2 at different temperatures. (a1, b1) $600{ }^{\circ} \mathrm{C},(\mathbf{a} 2, \mathbf{b 2}) 700{ }^{\circ} \mathrm{C}$, $(\mathbf{a} 3, \mathbf{b 3}) 800{ }^{\circ} \mathrm{C},(\mathbf{a} 4, \mathbf{b 4}) 900{ }^{\circ} \mathrm{C}$, and $(\mathbf{a} 5, \mathbf{b 5}) 1000{ }^{\circ} \mathrm{C}$, Figure S11: TG-DSC plots of (a) $\mathrm{NaFeTiO}_{4}$ needles and (b) $\mathrm{Na}_{0.75} \mathrm{Fe}_{0.75} \mathrm{Ti}_{0.25} \mathrm{O}_{2}$ platelets.

Author Contributions: Conceptualization, L.S. and N.B.; methodology, L.S. and N.B.; validation, H.Z., M.L., and Z.Z.; formal analysis, H.Z. and M.L.; investigation, H.Z. and M.L.; resources, H.Z., M.L., and Z.Z.; data curation, H.Z. and M.L.; writing-original draft preparation, H.Z. and M.L.; writing-review and editing, L.S. and N.B.; supervision, L.S. and N.B.; project administration, L.S. and N.B.; funding acquisition, L.S. and N.B. 
Funding: This research was supported by the Natural Science Foundation of China (No. 51425202, No. 51772150), the Natural Science Foundation of Jiangsu Province (BK20160093), and the Project Funded by the Priority Academic Program Development of Jiangsu Higher Education Institutions (PAPD).

Conflicts of Interest: The authors declare no conflict of interest.

\section{References}

1. Ohsaka, T.; Fujiki, Y. Raman spectra in hollandite type compounds $\mathrm{K}_{1.6} \mathrm{Mg}_{0.8} \mathrm{Ti}_{7.2} \mathrm{O}_{16}$ and $\mathrm{K}_{1.6} \mathrm{Al}_{1.6} \mathrm{Ti}_{6.4} \mathrm{O}_{16}$. Solid State Commun. 1982, 44, 1325-1327. [CrossRef]

2. Endo, T.; Nagayama, H.; Sato, T.; Shimada, M. Crystal growth of potassium titanates in the system $\mathrm{K}_{2} \mathrm{O}-\mathrm{Fe}_{2} \mathrm{O}_{3}-\mathrm{TiO}_{2}$. J. Cryst. Growth. 1986, 78, 423-430. [CrossRef]

3. Park, Y.; Terasaki, K.; Igarashi, K.; Shimizu, T. Manufacture and mechanical properties of magnesium potassium titanate short fiber/glass composite. Adv. Compos. Mater. 2001, 10, 17-28. [CrossRef]

4. Chen, M.; Wang, Z.; Liu, H.; Wang, X.; Ma, Y.; Liu, J. Synthesis of potassium magnesium titanate whiskers with high near-infrared reflectivity by the flux method. Mater. Lett. 2017, 202, 59-61. [CrossRef]

5. Akieh, M.N.; Lahtinen, M.; Vaisanen, A.; Sillanpaa, M. Preparation and characterization of sodium iron titanate ion exchanger and its application in heavy metal removal from waste waters. J. Hazard. Mater. 2008, 152, 640-647. [CrossRef] [PubMed]

6. Knyazev, A.V.; Chernorukov, N.G.; Ladenkov, I.V.; Belopol'skaya, S.S. Synthesis, structure, and thermal expansion of $\mathrm{M}_{2} \mathrm{Fe}_{2} \mathrm{Ti}_{6} \mathrm{O}_{16}$ and $\mathrm{MFeTiO}_{4}$ Compounds. Inorg. Mater. 2011, 47, 999-1005. [CrossRef]

7. Hou, J.; Niu, Y.; Yi, F.; Liu, S.; Li, Y.; He, H.; Xu, M. NaTi ${ }_{3} \mathrm{FeO}_{8}$ : A novel anode material for sodium-ion batteries. RSC Adv. 2015, 5, 44313-44316. [CrossRef]

8. Archaimbault, F.; Choisnet, J. The defect solid-solution $\mathrm{Na}_{7 / 8}\left(\mathrm{Fe}^{\mathrm{III}}{ }_{7 / 8+\mathrm{x}} \mathrm{Ti}^{\mathrm{IV}}{ }_{9 / 8-2 \mathrm{x}} \mathrm{Sb}_{\mathrm{x}} \mathrm{V}^{\mathrm{V}}\right) \mathrm{O}_{4}(0 \leq \mathrm{x} \leq 1 / 3)$ : Evidence of $\mathrm{Na}^{1}$ mobility in the tunnels of a quadruple rutile-chain structure. J. Solid State Chem. 1991, 90, $216-227$. [CrossRef]

9. Mumme, W.G.; Reid, A.F. Non-stoichiometric sodium iron titanate, $\mathrm{Na}_{\mathrm{x}} \mathrm{Fe}_{\mathrm{x}} \mathrm{Ti}_{2-\mathrm{x}} \mathrm{O}_{4},(0.90>\mathrm{x}>0.75)$. Acta Cryst. 1968, 24, 625-631. [CrossRef]

10. Kuhn, A.; Leon, C.; Garcia-Alvarado, F.; Santamaria, J.; Moran, E.; Alario-Franco, M.A. Study of the conductivity of Nax- $\sigma \mathrm{Fe}_{\mathrm{x}} \mathrm{Ti}_{2-\mathrm{x}} \mathrm{O}_{4}(\mathrm{x}=0.875,0 \leq \sigma \leq 0.4)$. J. Solid State Chem. 1998, 137, 168-173. [CrossRef]

11. Tan, Y.; Song, N.; Liu, Y.; Luo, T.; Dou, Y.; Zhang, Q.; Liu, Q.; Luo, L. Synthesis of platy potassium magnesium titanate and its application in removal of copper ions from aqueous solution. Trans. Nonferrous Met. Soc. China 2015, 25, 981-990. [CrossRef]

12. Liu, M.; Liu, Y.; Zhang, D.; Liu, B.; Guo, Y. Nickel ion removal by porous potassium magnesium titanate made from plate-like crystals. Adv. Appl. Ceram. 2015, 114, 456-464. [CrossRef]

13. Fujishiro, Y.; Miyata, M.; Awano, Y.; Maeda, K. Thermoelectric characterization of $\mathrm{Na}_{x} \mathrm{M}_{\mathrm{x} / 2} \mathrm{Ti}_{1-\mathrm{x} / 2} \mathrm{O}_{2}(\mathrm{M}=\mathrm{Co}$, $\mathrm{Ni}$ and $\mathrm{Fe}$ ) polycrystalline materials. Ceram. Int. 2003, 28, 841-845. [CrossRef]

14. Li, C.; Reid, A.F.; Saunders, S. Nonstoichiometric alkali ferrites and aluminates in the systems $\mathrm{NaFeO}_{2}-\mathrm{TiO}_{2}$, $\mathrm{KFeO}_{2}-\mathrm{TiO}_{2}, \mathrm{KAlO}_{2}-\mathrm{TiO}_{2}$, and $\mathrm{KAlO}_{2}-\mathrm{SiO}_{2}$. J. Solid State Chem. 1971, 3, 614-624. [CrossRef]

15. Thorne, J.S.; Chowdhury, S.; Dunlap, R.A.; Obrovac, M.N. Structure and electrochemistry of $\mathrm{Na}_{\mathrm{x}} \mathrm{Fe}_{\mathrm{x}} \mathrm{Ti}_{1-\mathrm{x}} \mathrm{O}_{2}$ $(1.0 \geq x \geq 0.75)$ for Na-Ion battery positive electrodes. J. Electrochem. Soc. 2014, 161, A1801-A1805. [CrossRef]

16. Plumley, A.L.; Orr, W.C. Replacement of Potassium Ions in Solid Potassium Hexatitanate by Sodium Ions from a Chloride Flux. J. Am. Chem. Soc. 1961, 83, 1289-1291. [CrossRef]

(C) 2019 by the authors. Licensee MDPI, Basel, Switzerland. This article is an open access article distributed under the terms and conditions of the Creative Commons Attribution (CC BY) license (http://creativecommons.org/licenses/by/4.0/). 